\title{
ŻYCIE W OBRAZIE. O KONCEPCJI MALARSKIEJ WASSILEGO KANDINSKY'EGO
}

(0) wą drugą książkę, wydaną w 1926 r. w Monachium, Wassily Kandinsky rozpoczął wprowadzeniem, w którym dokonał rozróżnienia dwóch perspektyw, z jakich można przeżywać każde zjawisko. Pierwsza, zewnętrzna, polega na obserwowaniu jakby przez szybę okienną. Rzeczywistość oglądana przez nią ukazuje się jako „odizolowana, pulsująca po »tamtej stronie «" 1 . Punkt widzenia wewnętrzny polega na „otwarciu drzwi” i „zagłębianiu się w owej rzeczywistości, uaktywnianiu się w niej i przeżywaniu jej pulsowania wszystkimi zmysłami"2. Dzieło sztuki, twierdzi autor, sytuuje się na zewnątrz nas, a więc również w przypadku zetknięcia się z nim pojawia się „niby-szyba” uniemożliwiająca nawiązanie bezpośredniego kontaktu.

Jednakże - pisze dalej - istnieje również możliwość penetracji w głąb dzieła sztuki, przeżywania jego wewnętrznego pulsowania aktywnie i wszystkimi zmysłami ${ }^{3}$.

Kandinsky nie rozwija tego wątku w pełnym zakresie. Ma tego świadomość, gdyż pisze w końcowej części wprowadzenia: „brak mi nie tylko umiejętności, aby początkowe przynajmniej uściślenia dostatecznie dokładnie przeprowadzić, ale także i miejsca"4. Koncentruje się na tylko jednym zagadnieniu - teoretycznym „rozkładaniu” utworu dla lepszego poznania go i na pytaniu, czy stać się to może kluczem do „sekretnego pulsowania dzieła sztuki”. Stara się przekonać, że jest to możliwe, jednak zdaje sobie sprawę, że wiedza ta może tylko częściowo zbliżyć do żywej sytuacji kontaktu ze sztuką.

1 W. Kandyński, Punkt i linia a płaszczyzna. Przyczynek do analizy elementów malarskich, tłum. S. Fijałkowski, Warszawa 1986, s. 12.

2 Ibidem.

${ }^{3}$ Ibidem, s. 12-13.

${ }^{4}$ Ibidem, s. 17. 
Uważam, że rozróżnienie zewnętrznego i wewnętrznego punktu widzenia ma istotne znaczenie dla zrozumienia koncepcji malarskiej W. Kandinsky'ego. W tradycyjnym malarstwie, a także w teorii sztuki zakładane było, że przedstawiana na obrazie rzeczywistość znajduje się jakby za szybą. Kwestię tę ujął znakomicie Leone Battista Alberti w swej słynnej metaforze, mówiącej, że na obraz należy patrzeć jak na okno. Jej interpretatorzy zwykle koncentrowali się na jednej konsekwencji: odbiorca nie powinien skupiać uwagi na płaszczyźnie malowidła, a poprzez nią ujmować przedstawioną rzeczywistość. Kandinsky wyraźnie nawiązuje w swym tekście do tego sformułowania, jednak podnosi w związku z nim inny problem. Pyta, czy można ominąć „niby-szybę” albo otworzyć okno i zetknąć się bezpośrednio z rzeczywistością, nawiązać kontakt z życiem. W przypadku obrazu nie będzie nim jednak scena przedstawiona, ukazana mniej lub bardziej iluzjonistycznie za pomocą środków malarskich. Nawet jeśli jest ona pokazana w sposób bardzo zbliżony do wyglądu rzeczywistości, pozostaje zamknięta dla odbiorcy, który w sensie fizycznym nie może do niej przeniknąć. Czy nie ma jednak innych sposobów „penetracji”, jak to określa artysta, w głąb dzieła sztuki?

Analogiczna sytuacja zdaje się występować w przypadku tradycyjnego teatru. Tu również istnieje podział na scenę i widownię, które oddziela „niby-szyba” równie nieprzenikalna, jak w przypadku obrazu malarskiego. Wprawdzie wejście widza na scenę jest fizycznie możliwe, ale zabrania tego konwencja teatralna. Podjęcie takiego działania skończyłoby się represjami zarówno ze strony pracowników ochrony, jak i innych widzów, którzy uznaliby ją za zakłócenie porządku. Próby przełamania tej sytuacji wystąpiły jednak w happeningach i sztuce performansu. W przypadku tych działań „niby-szyba” nie istnieje w dwojakim znaczeniu. Przede wszystkim w sensie fizycznym, gdyż zlikwidowany został podział na scenę i widownię. Uczestnicy tych działań artystycznych znajdują się w tej samej przestrzeni co performerzy, a w przypadku happeningów zaprasza się ich nawet do włączania się w akcję. Co ważniejsze jednak z punktu widzenia tego artykułu, znika podział na kreowaną w tradycyjnym teatrze fikcyjną rzeczywistość i realne życie, które przeżywają widzowie. Zarówno happeningi, jak i realizacje performerskie rozgrywają się $\mathrm{w}$ realnym czasie i w konkretnym miejscu. Natomiast same działania nie mają być opowieściami o życiu czy przedstawieniem życia, lecz zdarzeniami włączającymi się do niego ${ }^{5}$.

${ }^{5}$ Por. np. M. Kirby, Happenings, New York 1965; Happenings and Fluxus, red. H. Sohm, Köln 1970; T. Pawłowski, Happening, Warszawa 1982; R. Goldberg, Performance. Live Art Since 1960, London-New York 1998; Performance. Wybór tekstów, red. G. Dziamski, H. Gajewski, J.S. Wojciechowski, Warszawa 1984. 
Czy w malarstwie możliwe jest zlikwidowanie „niby-szyby” w sposób analogiczny do tego, w jaki nastąpiło to w przypadku happeningów i performance art? Wydaje się to nie do zrealizowania ze względów fizycznych, chyba że za spełnienie tego postulatu uznamy „żywe obrazy” popularne na przełomie XIX i XX w. Wydaje się jednak, że w przypadku tego rodzaju działań mniej chodziło o wyjście w kierunku życia, a bardziej o wzniesienie konkretnego miejsca i osób do poziomu sztuki. „Żywe obrazy” wykonywano przecież możliwie dokładnie, odtwarzając sceny zakomponowane wcześniej w malarstwie. Miały one być rodzajem hołdu składanego wybitnym malarzom albo dokonanym za pośrednictwem ich dzieł upamiętnieniem wydarzeń historycznych. W drugim przypadku obraz rekonstruowany „na żywo" traktowano jako ukazanie kwintesencji przywoływanego zdarzenia ${ }^{6}$.

Jak zatem W. Kandinsky wyobrażał sobie możliwość malarskiego wyjścia ku życiu? Gdy

wychodzimy z zamkniętego wnętrza na zewnątrz - pisał - zagłębiamy się w ową rzeczywistość, uaktywniamy się w niej i przeżywamy jej pulsowanie wszystkimi zmysłami

Podobnie może być, jak sądził, gdy zrezygnujemy z traktowania obrazu jako przedstawienia rzeczywistości i poddamy się bezpośredniemu oddziaływaniu samych elementów plastycznych. Są one konkretami wywierającymi wpływ swoim kształtem, wielkością, barwą, umiejscowieniem. Brakuje im jednak składnika życia, jakim jest ruch. Dopiero bowiem, gdy

ogarnia nas ruch - gra poziomych i pionowych kresek i linii odchylających się na wszystkie strony w trakcie naszego poruszania się oraz plam barwnych skupiających się i rozsypujących, dźwięczących raz wysoko, raz znów nisko ${ }^{8}$,

mamy poczucie zagłębienia się w rzeczywistości. Czy jednak dla malarstwa problem ten stanowi nieprzekraczalną barierę? Czy rzeczywiście w obrazach ruch nie istnieje? Kandinsky w swej drugiej książce z 1926 r. postanowił poddać ten problem analizie. Zagadnienie ruchu interesuje go jednak nie tyle $w$ aspekcie zmysłowo-fizycznym (jako sugestia poruszania się elementów statycznych występujących na płótnie), co psychicznym, jako kwestia wewnętrznego pulsowania odbieranego wszystkimi zmysłami i wywołującego rezonans emocjonalny. Zjawisko to określił jako „brzmienie wewnętrzne" elementów plastycznych. Powoduje ono, że kontakt z nimi sprawia wrażenie obcowania z żywymi istotami.

\footnotetext{
${ }^{6}$ Por. M. Komza, Żywe obrazy. Między scenq, obrazem i książka, Wrocław 1995.

${ }^{7}$ W. Kandyński, op. cit., s. 12.

${ }^{8}$ Ibidem.
} 
Zagadnienie omawia najpierw na przykładzie punktu. Na początku rozważa go w ujęciu matematycznym. Podstawowy element geometrii traktowany jest wówczas jako pozbawiony rozmiaru i kształtu, a więc niewidoczny. Jednak zdaniem artysty punkt ma nawet $\mathrm{w}$ takim czysto pojęciowym rozumieniu „rozmaite »ludzkie« właściwości” - „jest wyrazem największej zwięzłości, najbardziej wymownej powściągliwości", stanowi dla nas „najściślejsze i zupełnie wyjątkowe połączenie milczenia i wy mowy [podkreślenie w oryginale - P.Sz.]" ${ }^{\prime}$. Przykład ten jest bardzo charakterystyczny. Kandinsky rozważa coś, co zgodnie z ustaleniami matematycznymi istnieje wyłącznie pojęciowo, a jednak odkrywa w geometrycznej idei punktu ludzki sens. Bierze też pod uwagę inne pozaplastyczne przykłady „wymowy” punktu, np. jako znaku przestankowego w tekście pisanym. Podkreśla, że ów aspekt „semantyczny” może być często niedostrzegany ze względu na występującą w życiu codziennym konwencjonalizację sposobu używania różnych elementów pisma. Wyrwać nas mogą z tej sytuacji „wstrząsy” burzące zasadę praktycznej celowości, przesłaniającej ich „wymowę”. Choroba, nieszczęście, troska, wojna, rewolucja, zauważa W. Kandinsky, uwolnić nas mogą od codziennej rutyny nawykowego traktowania poszczególnych elementów i skłonić do odkrycia ich nowego sensu. Autor zaznacza jednak, że najistotniejszy jest szok innego rodzaju, „pochodzący od wewnątrz”, który powoduje sam człowiek i który ma „swe źródło $\mathrm{w}$ jego osobowości”10. Zaznacza jednak przy tym istotną rolę wrażeń zmysłowych. Są one skoncentrowane na formach przedmiotów. Zwykle składające się na nie cechy są brane pod uwagę tylko częściowo, w zakresie istotnym z punktu widzenia ich funkcji praktycznej. Inne aspekty przedmiotów pozostają dla ludzi nieistotne, „nieaktywne”. Artysta może je uwzględnić, zaktywizować. W ten sposób

nieme dotąd otoczenie zaczyna przemawiać do nas coraz bardziej zrozumiałymi głosami. Puste dotąd znaki stają się żywymi symbolami, to, co było martwe, zostaje wskrzeszone ${ }^{11}$.

Kandinsky w swej książce rozważa zabiegi, dzięki którym „martwy punkt staje się żywą istotą" ${ }^{12}$. Nie chce jednak pozostawić tej kwestii nieprzewidywalnym decyzjom odbiorcy, lecz stara się wskazać, w jaki sposób działania twórcy obrazu odnoszące się do formy mogą wpływać na uwolnienie elementu od konwencjonalnego zastosowania i dać mu szansę funkcjonowania jako „przedmiotu samoistnego”, mogącego wywoływać reakcje emocjonalne

\footnotetext{
9 Ibidem, s. 19.

10 Ibidem, s. 20.

11 Ibidem, s. 21.

12 Ibidem.
} 
u widzów. Biorąc pod uwagę punkty występujące w malarstwie i grafice, W. Kandinsky podkreśla, że w przeciwieństwie do idei punktu w geometrii zawsze mają one określoną wielkość i kształt. Zmienia to i modyfikuje ich „brzmienie”. Tym jednak, co łączy je z wcześniej omówionymi odmianami, jest brak „rozciągłości czasowej”. Artysta wskazuje też przykłady występowania skupisk punktów (nie w geometrycznym, lecz zmaterializowanym wizualnie znaczeniu) w przyrodzie oraz w mikro - i makrokosmosie. W przyrodzie podaje przykład makówki:

gdy otworzymy piękną, gładką, ciepłą w tonie makówkę (ostatecznie jest ona również kulistym punktem), odkrywamy w jej wnętrzu gromady kompozycyjnie prawidłowo rozmieszczonych, zimnych, niebieskoszarych punktów, w których drzemią siły rozrodcze rośliny, zupełnie tak samo jak w punkcie tkwi w zarodku forma malarska ${ }^{13}$.

Warto w tym cytacie zwrócić uwagę na uwzględnianie skojarzeń o charakterze synestetycznym. Główka makówki jest „ciepła w tonie”, a znajdujące w niej ziarenka „zimne”. Uwzględnienie takich skojarzeń dodatkowo wzmaga możliwości wzbogacania odczuć związanych z cechami przedmiotów. Za nagromadzenie punktów w skali makro Kandinsky uważa pustynię. Pisze, że jest ona

całym morzem piasku, składającym się w końcu wyłącznie z punktów, i nie bez powodu niesłychana lotność, niepohamowana zdolność wędrówki tych „martwych” punktów działa na nas deprymująco ${ }^{14}$.

W formie ilustracji zamieszczonych w książce dodaje jeszcze gromadę kulistą w gwiazdozbiorze Herkulesa zaczerpniętą z podręcznika astronomii i oglądane pod mikroskopem związki azotu w 1000-krotnym powiększeniu.

Warto zwrócić uwagę na przebieg asocjacyjny występujący w związku z tym gromadzeniem przykładów. Nie opiera się on na zasadzie mimetycznego odwzorowania (makówka, pustynia, gwiazdozbiór lub związki azotu - układ punktów na rysunku jako ich przedstawienie), lecz na zasadzie znajdowania odniesień w naturze dla wykonanego rysunkowo zbioru elementów punktowych. Myślenie malarza zaczyna się więc od organizacji konkretnych elementów graficznych na płaszczyźnie. Działalność plastyczna jest pierwotna. Podobną drogę postępowania W. Kandinsky zalecał już w wydanej 14 lat wcześniej książce 0 duchowości $w$ sztuce, gdzie pisał, że „działanie koloru” trzeba rozważać, nie obserwując barwy w otaczającym nas świecie,

\footnotetext{
13 Ibidem, s. 37.

14 Ibidem, s. 37.
} 
lecz przyglądając się im wyciśniętym na palecie ${ }^{15}$. Działania artystyczne skoncentrowane są więc na operowaniu środkami plastycznymi jako tworami materialnymi i braniu pod uwagę pojawiających się rezultatów ich użycia. W tym zakresie artysta uwzględniał zarówno skojarzenia mimetyczne, przedstawieniowe, jak i czysto emocjonalne, gdy dotyczyły kształtów nieprzedstawiających.

Kolejnym rozważanym przez autora elementem plastycznym była linia. W przeciwieństwie do punktu, który cechuje brak ruchu, linia jest zawsze dynamiczna, gdyż powstaje przez uruchomienie punktu pod wpływem działającej na niego siły. Gdy jest to jedna siła, powstaje linia prosta. Ze względu na kierunek działania linie mogą być poziome, pionowe i przekątne. Jeśli w czasie przebiegu linii oddziałuje w niej lub na nią więcej sił, jej kształt stanie się bardziej złożony i przybierze charakter łamany lub falisty. Jednak W. Kandinsky'ego interesowało nie tylko rozpatrywanie różnych szczegółowych odmian tych działań, lecz także wpływ uzyskanych efektów na psychikę widza. Już rozważając linie proste, zwracał uwagę, że pozioma jest „najzwięźlejszą zimną formą ruchu w nieskończoność"16. Na jakiej podstawie formułował tę opinię? Wyjaśniając, pisał:

W ludzkiej wyobraźni odpowiada ona linii lub płaszczyźnie, na której człowiek stoi albo porusza się. Linia pozioma jest więc chłodną [z powodu pewnej pasywności - P.Sz.], dźwigającą podstawą, która może być płasko przedłużana w obu kierunkach. Płaskie rozpościeranie się i chłód to podstawowy wyraz [dźwięk - P.Sz.] tej linii1 ${ }^{17}$.

Zakładał więc, że wyraz emocjonalny elementu plastycznego poznajemy dzięki przeniesieniu się w rzeczywistość oglądanego kształtu. Jeśli na skutek działania wyobraźni będziemy poruszali się wraz z przesuwającym się punktem tworzącym linię, poznamy jej wyraz. Linia pozioma jest chłodna, ponieważ ruch płaski nie wymaga wiele wysiłku. Linia pionowa wznosi się, a więc jej ruch wymaga większego stopnia aktywności, a zatem ma „podwyższoną temperaturę".

Właściwe dla tej teorii ożywienie oglądanych kształtów występuje również w przypadku figur geometrycznych. Charakteryzując powstanie okręgu, W. Kandinsky stwierdzał:

Prawdę mówiąc, także i linia prosta, obok innych właściwości, nosi w sobie - aczkolwiek głęboko ukryte - pragnienie przerodzenia się w płaszczyznę, przekształcenia się w formę bardziej zwartą i bardziej zamkniętą w sobie.

${ }^{15}$ W. Kandyński, O duchowości w sztuce, tłum. S. Fijałkowski, Łódź 1996, s. 58.

16 Idem, Punkt..., s. 57.

${ }^{17}$ Ibidem, s. 57. 
Jest też w stanie to uczynić, choć dla utworzenia płaszczyzny potrzebne są trzy uderzenia siły ${ }^{18}$.

W podobny sposób ujmował powstanie innych figur. Jednocześnie zaś starał się określić relacje między nimi, biorąc przy tym pod uwagę oddziaływanie emocjonalne. Zakładał też możliwość uwzględnienia relacji między systemem elementów plastycznych (malarskich i graficznych) oraz systemami właściwymi dla innych dziedzin sztuki.

Elementy przestrzenne w rzeźbie i architekturze, elementy dźwiękowe w muzyce, elementy ruchowe w tańcu, a słowne w poezji - pisał - domagają się podobnego ukazania ich w czystej postaci oraz podobnie elementarnego zestawienia ze względu na ich własności zewnętrzne i wewnętrzne, które nazywamy dźwiękami ${ }^{19}$.

Proponował więc przyjęcie terminologii zapożyczonej z teorii muzyki, gdzie najwcześniej taki rodzaj myślenia o sztuce się pojawił.

Podobny sposób podejścia do elementów plastycznych W. Kandinsky przenosił również na zagadnienia kompozycji.

Tak wiec kompozycja - pisał - nie jest niczym innym niż ściśle prawidłową organizacją żywych sił, zamkniętych wewnątrz elementów w postaci napięć ${ }^{20}$.

Sformułowanie to tylko częściowo przypomina tradycyjną koncepcję formy artystycznej rozumianej jako organiczna jedność elementów ${ }^{21}$. W tej sięgającej starożytności teorii zwracano uwagę tylko na sposób organizacji elementów, który powinien przypominać pod względem zwartości, spójności żywe organizmy - składniki powinny być podporządkowane całości. Tymczasem u W. Kandinsky'ego pojawia się założenie, że same składniki też obdarzone są życiem według opisanej wyżej zasady, zaś całościowa kompozycja dzieła to organizacja tych żywych sił.

W omawianej tu koncepcji pojawiają się też elementy dodatkowe. Rozdział poświęcony szczegółowej prezentacji zagadnienia kompozycji plastycznej rozpoczyna się od omówienia roli płaszczyzny. Dla artysty nie jest ona neutralnym podłożem, na którym przedstawiona zostanie gra kształtów i barw. Ma ona swój własny charakter, dzięki czemu aktywnie włącza się w całościowe działanie obrazu.

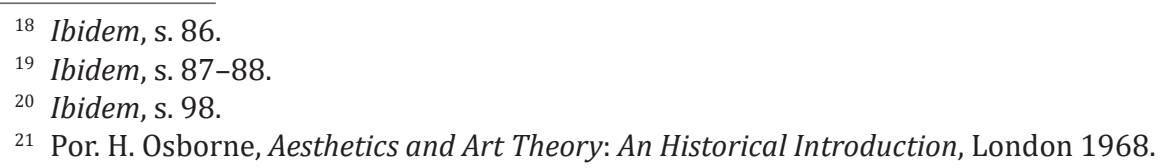


Doświadczenie każdej żywej istoty, która stale zajmuje i musi zajmować jakąś pozycję w stosunku do góry i dołu - pisze - przenosi się na PO [Płaszczyznę Obrazu - P.Sz.], która jako taka jest sama żywym organizmem. Da się to częściowo wyjaśnić przez asocjację, po części przez transpozycję własnych obserwacji ${ }^{22}$.

Kandinsky zauważa jednak również, zgodnie z zasadą animizacji, że płaszczyzna ta ma „charakter żywej istoty”. Przekonanie takie musiało być mu bliskie, gdyż rozwijał tę myśl, pisząc, że artysta

odczuwa, choćby nieświadomie, żywe tchnienie nie naruszonej jeszcze PO, że mniej lub więcej świadomie czuje swą odpowiedzialność w stosunku do niej, że zdaje sobie sprawę z tego, iż lekkomyślne pogwałcenie jej ma w sobie coś ze zbrodni. Artysta „zapładnia” ją i wie, jak posłusznie i pokornie PO przyjmuje właściwe i prawidłowo uporządkowane elementy. Ten prymitywny wprawdzie, żywy jednak organizm przekształca się na skutek właściwego traktowania w organizm nowy, już nie tak prymitywny - przeciwnie, wykazujący wszelkie cechy organizmu rozwiniętego ${ }^{23}$.

W rozważaniach nad obrazem prowadzonych przez W. Kandinsky'ego powtarzane są wciąż określenia „żywy” i „życie”. Stosowane są one w przypadku składników malarstwa takich jak punkty i linie, układów kompozycyjnych, a nawet niezamalowanej płaszczyzny obrazu. Nie chodzi przy tym o wyróżnienie pewnych odmian elementów czy rozwiązań kompozycyjnych na zasadzie przeciwstawienia ich innym, np. kompozycji statycznej (jako martwej) i kompozycji dynamicznej (kojarzącej się ruchem jako atrybutem życia). Uważał on, że wszystkie odmiany układów składników obrazu cechuje swoiste życie. Postulował też, w konsekwencji, przekroczenie podziału na sztuki aktorskie, w których występują żywe osoby (teatr, pantomima, balet) i sztuki przedmiotowe, w których odbiorca ma do czynienia z pozbawionymi życia obiektami ${ }^{24}$. Sugerował, żeby uwzględnić

głębokie powinowactwa istniejące pomiędzy rozmaitymi dziedzinami sztuki, co z kolei pozwala przeczuwać głęboko leżące wspólne korzenie wszelkiej twórczości, a w końcu wszelkiej duchowej ludzkiej działalności²5.

Z punktu widzenia związku sztuk rozważane są zwykle sugestie W. Kandinsky'ego dotyczące analogii między malarstwem i muzyką. Znajdowały one wyraz $\mathrm{w}$ terminologii stosowanej przez niego podczas analizowania

${ }^{22}$ W. Kandyński, Punkt..., s. 128-129.

${ }^{23}$ Ibidem, s. 129.

${ }^{24}$ Przykładem może być graficzna analiza jednej z figur tanecznych jako układu linii i punktów (por. „Skok w górę tancerki Palukki” i „Graficzny schemat skoku”, ibidem, s. 41).

${ }^{25}$ Ibidem, s. 134. 
malarstwa. W artykule tym chciałabym wziąć pod uwagę relacje malarstwa oraz tych dziedzin twórczości, w których mamy do czynienia z życiem i działaniem żywych osób w określonym otoczeniu rzeczy. Chcę więc podjąć kwestię performatywnego charakteru koncepcji artystycznej W. Kandinsky'ego. We wstępnej części artykułu odwoływałam się do roli „niby-szyby” i jej przezwyciężania w teatrze, happeningu i sztuce performansu. Jak - biorąc pod uwagę te odniesienia - określić można charakter malarskich propozycji rosyjskiego artysty?

Przede wszystkim, jeśli założyć różnicę między teatrem a sztuką performansu, to koncepcja W. Kandinsky'ego bliższa jest pierwszemu z tych pojęć ${ }^{26}$. Christopher Balme zwraca uwagę, że w sztuce performansu dochodzi do zastąpienia aspektu referencyjnego (przedstawianie postaci, przebieg akcji, odtwarzanie sytuacji) przez „performatywny wymiar”. 0 ile więc $\mathrm{w}$ tradycyjnej teorii teatru akcent padał na wytwarzanie znaczeń, w performansie akcentowane jest samo wykonywanie działań ${ }^{27}$. W przypadku koncepcji W. Kandinsky'ego, gdy rozpatrujemy ją z punktu widzenia tych różnic, mamy do czynienia z zaakcentowaniem pierwszej z wyróżnionych możliwości. Traktując płaszczyznę malarską czy rysunkową jako rodzaj sceny, artysta przedstawia na niej elementy plastyczne jak „postaci”, które mają stworzyć widowisko. Bierze więc pod uwagę ich charakterystykę i analizuje rolę, jaką mają do odegrania. Uwzględniając omówione tu cechy dynamiczne, rozważa „przebieg akcji”, możliwości ruchu, kształtujące się sytuacje. Określają one znaczenie obrazu analogicznie do kształtowania się sensu w przypadku przedstawienia teatralnego.

Rola malarza w koncepcji W. Kandinsky'ego przypomina rolę reżysera w teatrze. W obu przypadkach działanie polega raczej na aranżowaniu sytuacji na płaszczyźnie lub na scenie niż na bezpośrednim działaniu. Kandinsky już w pierwszej książce podzielił swe obrazy na trzy odmiany: Impresje, Improwizacje i Kompozycje. Pierwsza odmiana to „bezpośrednie wrażenia

${ }^{26}$ Christopher Balme kwestionuje w znacznym stopniu zasadność tego rozróżnienia, choć nie odrzuca w pełni jego użyteczności. Pisze, że pojęcia „działanie” albo „akcja” z punktu widzenia teatru, który zawsze polegał na „sztuce działania”, nie mają znaczącej siły wyrazu. Ponadto uważa, ze „niemożność zdefiniowania sztuki peformance leży niejako w jej naturze, bo każda próba definicji bywa natychmiast podważona przez nowe zjawisko, które podaje w wątpliwość sens poprzedniego określenia. Kiedy na przykład Elisabeth Jappe pisze: »Performance jest zawsze autentyczny: wykonawcy są wyłącznie sobą, a czas i przestrzeń - realne« (eadem, Performance - Ritual - Prozeß: Handbuch der Aktionskunst in Europa, München-New York 1993, s. 10), to odnosi się to do artystów lat siedemdziesiątych. Dzisiaj obserwuje się bowiem tendencję do fikcjonalizacji, co obala postulat autentyzmu" (Ch. Balme, Wprowadzenie do nauki o teatrze, tłum. W. Dudzik, M. Leyko, Warszawa 2002, s. 216). Uwzględniam jednak tę różnicę, gdyż pozwala ona zwrócić uwagę na istotne cechy koncepcji twórczej W. Kandinsky’ego.

${ }^{27}$ Ibidem, s. 219. 
$\mathrm{z}$ »natury«, wyrażone w formie rysunkowo-malarskiej"28. Druga stanowi natomiast

przeważnie nieświadome, po większej części powstałe spontanicznie, doznania spowodowane przeżyciami o charakterze wewnętrznym, wrażenia „natury wewnętrznej”29.

Obie te odmiany traktuje jednak jako rodzaj przygotowania do wykonania Kompozycji. Określa tak „wypowiedzi” malarskie powstające wyjątkowo wolno, „które długo i nieledwie pedantycznie są [...] weryfikowane i opracowywane na podstawie pierwszych szkiców"30.

Wyodrębnione trzy odmiany prac malarskich przypominają ukształtowany w sztuce nowożytnej i usankcjonowany w akademizmie podział na szkice lub studia i właściwe dzieła sztuki. Analogię tę dodatkowo potwierdza wskazywany przez W. Kandinsky'ego sposób realizacji. W Impresjach chodzi o zatrzymanie efektu pierwszego wrażenia wzrokowego. W Improwizacjach liczą się emocje artysty i spontaniczna aktywność wykonawcza. W obu przypadkach nie ma miejsca na przemyślane komponowanie rozumiane jako „reżyserowanie” obrazu. Natomiast w odniesieniu do Kompozycji „stosunkowo największą rolę odgrywa rozsądek, świadomość, namysł, celowość" ${ }^{31}$. Taki porządek działań uwzględniany był w malarstwie od czasów renesansu. Leone Battista Alberti w traktacie $O$ malarstwie podkreślał, że najważniejszym dziełem malarza jest historia (istoria), której rolę w obrazie można porównać do roli tekstu teatralnego (tekstu dramatu, libretta itp.). Renesansowy teoretyk zalecał zresztą przy opracowywaniu tej części dzieła uwzględnianie motywów z dzieł literackich, a także korzystanie $\mathrm{z}$ „umiejętności stosowania różnych pomysłów" ${ }^{32}$, gdyż wzbogaca to inwencję. Dalej pisał, że częściami historii są poszczególne ciała przedstawione w obrazie. Sugerował, że wskazane jest ich bogactwo, tzn. powinni znaleźć się

odpowiednio rozmieszczeni starcy, mężowie w sile wieku, młodzieńcy, chłopcy, poważne kobiety, dziewczęta, niemowlęta, oswojone zwierzęta, psy, ptaki, konie, bydło, gmachy, krajobrazy ${ }^{33}$.

Najważniejsze z nich to postacie ludzkie pokazane podczas wykonywania określonych ruchów. Mają one wyrażać określone uczucia i sugerować

\footnotetext{
${ }^{28}$ W. Kandyński, O duchowości..., s. 132.

${ }^{29}$ Ibidem, s. 133.

30 Ibidem.

31 Ibidem.

${ }^{32}$ L.B. Alberti, $O$ malarstwie, tłum. L. Winniczuk, Wrocław 1963, s. 51.

${ }^{33}$ Ibidem, s. 37.
} 
zmianę miejsca w przedstawionej na obrazie przestrzeni. Alberti zastanawia się, co należy zrobić, żeby ukazywane sceny zawierały najwięcej życia. Uważa, że sytuacja taka powstaje, „gdy postacie wykonują jak największą ilość ruchów, naśladują gestykulację aktorów"34. Bierze też pod uwagę efekt estetyczny przedstawianych działań. Pisze, że obraz powinien „przedstawiać ruchy wdzięczne, miłe i dostosowane do tego, co się dzieje w obrazie"35. W podobny sposób rozważa aranżację przedmiotów martwych (układy włosów, fałd szat) oraz elementów „scenograficznych” (np. gałęzi drzew). Celem jest,

ażeby każda część tak była dostosowana do tematu i nawet najdrobniejszy fragment związany z tematem tak odpowiadał całości, żeby ciała zmarłych robiły wrażenie martwych aż po same paznokcie, a w przedstawieniach postaci żywych wszystko robiło wrażenie życia ${ }^{36}$.

Sceną, na której w malarstwie rozgrywa się historia, jest płaszczyzna obrazu. Pracę nad jej zakomponowaniem przedstawiał L.B. Alberti jako wykreślenie dowolnej wielkości czworoboku o kątach prostych, stanowiącego „jak gdyby otwarte okno, przez które widać historię [podkreślenie w oryginale - P.Sz.]"37. Naniesiona zostanie na niego geometryczna konstrukcja perspektywiczna, która stworzy przestrzenne miejsce akcji. W nim rozegrane zostaną zdarzenia. Maria Rzepińska zauważa, że zasady zabudowy konstrukcji perspektywicznej w malarstwie wykazywały podobieństwo do organizacji sceny.

Taka budowa obrazu - pisze - ma wiele wspólnego z czynnościami architekta (rzuty boczne elewacji) oraz scenografa (ukształtowanie zamkniętej kubicznej przestrzeni z jedną otwartą ścianą od strony widzów - finestra aperta, ustawienie kulis - budynki, mury - rozmieszczenie postaci na pawimencie jakby na deskach scenicznych ${ }^{38}$.

Historyczka sztuki podkreśla też, że pojawiający się na obrazach układ postaci i przedmiotów nie był zaobserwowany w naturze. Zarówno w przypadku sceny teatralnej, jak i malarstwa stanowił wyreżyserowaną kompozycję w czasie i przestrzeni.

${ }^{34}$ Ibidem, s. 42 .

${ }^{35}$ Ibidem.

${ }^{36}$ Ibidem, s. 35-36. Warto zauważyć, że malarze, prezentując np. motywy biblijne czy mitologiczne, w różny sposób je „inscenizowali”, analogicznie do tego, jak może być różnie inscenizowany w teatrze ten sam tekst dramatu.

37 Ibidem, s. 19.

${ }^{38}$ M. Rzepińska, Wstęp, [w:] L.B. Alberti, op. cit., s. 49. 
Malarze XV i XVI wieku - podkreśla - nigdy nie malowali scen podpatrzonych wprost z natury (z wyjątkiem portretów). Było to malarstwo wyłącznie pracowniane albo fresk architektoniczny. Musieli zatem te obrazy zaaranżować, wyreżyserować, nie tylko z punktu widzenia formalnego, lecz dosłownie teatralnego, wyimaginować układ postaci wedle zamierzonej „inwencji”39.

Koncepcja „reżyserii” obrazu przedstawiona przez L.B. Albertiego powtórzona została później przez Leonarda da Vinci w Traktacie o malarstwie ${ }^{40}$, a dalej weszła w skład zasad akademickiej koncepcji sztuki, wywierającej istotny wpływ do XIX w. Stosowano w związku z tym terminy decorum (dostosowanie kompozycji i formy w dziele do charakteru jego tematu) oraz zapożyczony z teatru termin costume, oznaczający w tym przypadku znajomość historycznych akcesoriów ${ }^{41}$. Czy zagadnienia te można odnieść do malarstwa abstrakcyjnego, które uprawiał W. Kandinsky?

Gdy weźmiemy pod uwagę omówiony wcześniej autorski podział na typy obrazów, widać wyraźną odpowiedniość między Impresjami i Improwizacjami a uwzględnianymi w akademickiej koncepcji sztuki (choć mającymi swe źródło w teoriach renesansowych) croqius i esquisses. Croquis to chwytane na gorąco szkice postaci, scenek itp., natomiast esquisse to szkic kompozycyjny wykonany swobodnie i szybko ${ }^{42}$. Oba te pojęcia mają odpowiedniki w etapach pracy reżysera teatralnego nad przygotowywanym przedstawieniem. Odróżnić należy jednak od nich z jednej strony realizację sceniczną, a z drugiej Kompozycję w rozumieniu W. Kandinsky'ego. Tutaj występuje przygotowana we wcześniejszych fazach „świadoma i rozważna praca kompozycyjna"43. Sceną staje się płaszczyzna określonego formatu. Kandinsky w swych obrazach nie wykonuje na niej wykresu perspektywicznego przestrzeni, jednak bierze pod uwagę jej cechy (czy jest kwadratowa, wydłużona horyzontalnie lub wertykalnie) i przypisuje poszczególnym jej częściom określone wewnętrzne właściwości. Związane są one z odczuciami swobody ruchu i jego ograniczeniami czy zahamowaniami. Strona prawa, strona lewa, góra i dół „dźwięczą” inaczej, pojawia się w nich ton spokoju i ciepła albo wolności i skrępowania. W tak scharakteryzowanym na podstawie empatii obszarze $^{44}$ pojawiają się elementy plastyczne, czyli „aktorzy”. Każdy z nich ma własną charakterystykę ustaloną przez wczucie.

\footnotetext{
39 Ibidem.

40 Por. ibidem, s. 45-46.

${ }^{41}$ Por. eadem, Akademizm, Warszawa 1977, s. 57.

${ }^{42}$ Ibidem, s. 72.

${ }^{43}$ W. Kandyński, Punkt..., s. 133.

${ }^{44}$ Kandinsky pisze, że płaszczyzna obrazu stanowi „specjalne lustrzane odbicie artysty” (ibidem, s. 133).
} 
Kandinsky pracował nad wskazywaniem cech emotywnych głównych figur geometrycznych już w książce $O$ duchowości $w$ sztuce. W późniejszej pracy Punkt i linia a płaszczyzna tę charakterystykę rozwinął i uzupełnił rozważaniami na temat form bardziej skomplikowanych. Wykorzystał w tym celu kształty, które spontanicznie pojawiły się w jego Improwizacjach. Poddał je analizie, biorąc pod uwagę odczucia występujące podczas utożsamienia psychicznego z cechami obserwowanych linii lub figur. Przykładem może być swobodnie wygięta linia składająca się z dwóch łuków $\mathrm{z}$ jednej strony i trzech łuków z drugiej, pogrubiona stopniowo od dołu ku górze. Artysta pisze, że charakteryzuje ją „utemperowana pewność siebie”. $\mathrm{Z}$ powodu górnego, grubego szpica

ma wyraz zaciętego uporu, a kończy się u dołu coraz słabszym falowaniem. Linia ta zbiera się w sobie u dołu i rozprężając się ku górze, zyskuje coraz widoczniej na energii falowania aż do momentu osiągnięcia największej „Zaciętości”"45.

Kandinsky rozważa tę linię w dwóch ujęciach. Bierze też pod uwagę jej wygląd w zwierciadlanym odbiciu, czyli z drugiej strony. Twierdzi, że jej „treść" zmienia się istotnie:

zaciętość znika bez śladu, widzimy osłabienie jej napięcia. Do głosu dochodzi wyraz mozołu i wysiłku. Znika też poprzednia koncentracja, wszystko jest $\mathrm{w}$ trakcie stawania się. $\mathrm{W}$ momencie odwrócenia na lewo większego znaczenia nabiera rozwijanie się linii na prawo i wrażenie bardziej uciążliwego wysiłku ${ }^{46}$.

Rozpatrując te przykłady z punktu widzenia zakładanego tu pojmowania obrazu jako sceny, a kształtów jako aktorów, można powiedzieć, że nastąpiła zmiana charakteru postaci teatralnej, ujawnienie przez nią innych, nieprzewidywalnych wcześniej cech.

Komponowanie obrazu porównać można do zabiegów reżyserskich $\mathrm{w}$ teatrze. Poszczególne postacie biorące udział w przedstawieniu mają określony wygląd i charakter, którego domyślamy się na podstawie cech fizycznych i sposobu zachowania. Akcja sceniczna to modyfikacje, jakie w tym zakresie zachodzą w czasie spektaklu. Kandinsky uważa, że „przygody" elementu plastycznego mogą być związane ze zmianą jego miejsca na płaszczyźnie obrazu (dalej PO) lub ze względu na zachodzące spotkania z innymi kształtami. Biorąc pod uwagę pierwszą możliwość, pisze, że góra płaszczyzny sprawia odczucie „rozluźnienia”, „zaprzecza gęstości”, dlatego

45 Ibidem, s. 150.

${ }^{46}$ Ibidem, s. 151. 
każda ciężka forma umieszczona w górnej części PO zyskuje na wadze. [...] „Dół” oddziaływa zupełnie przeciwnie: zagęszczenie, ciężar, skrępowanie. Im bardziej zbliżamy się do dolnej krawędzi PO, tym gęściejsza staje się atmosfera, poszczególne maleńkie cząstki płaszczyzny zbliżają się do siebie, przez co tym łatwiej mogą udźwignąć coraz większe i cięższe formy. Same formy tracą na wadze, wrażenie ich ciężaru maleje. „Wznoszenie się” jest utrudnione, formy wydają się ledwo poruszać i słyszy się prawie, jak ocierają się o siebie - napięcie skierowane ku górze i spowolnione „opadanie” w dół. Swoboda „ruchu” staje się coraz bardziej ograniczona. Zah a mowania osiągają swe maksimum [podkreślenie w oryginale-P.Sz.] ${ }^{47}$.

Zajmowanie przez kształty plastyczne (aktorów) miejsc w obszarze płaszczyzny obrazu (sceny), a także w relacje między nimi stwarzają akcję malarską. Omawiając ją, W. Kandinsky bierze pod uwagę również „sens literacki". Powstaje on w związku z odniesieniem płaszczyzny obrazu do ciała człowieka i wczuwania rodzących się emocji w dzieło sztuki. Szczególne znaczenie $\mathrm{w}$ tym przypadku przypisuje odczuciom związanym $\mathrm{z}$ prawą i lewa stroną. "Jest to rezultat dwóch możliwości ruchu człowieka, które, mimo rozmaitych wariantów, w gruncie rzeczy są rzeczywiście jedyne"48.

Rozważając znaczenia i emocje pojawiające się $\mathrm{w}$ związku $\mathrm{z}$ sugestią ruchu w lewo, artysta pisze, że jest to droga

w daleki świat. $\mathrm{W}$ tę stronę oddalając się, człowiek opuszcza codzienne otoczenie, uwalnia się od ciążących mu konwencji i oporów hamujących jego swobodę; oddycha pełną piersią, wypuszcza się na „przygodę”. Formy o napięciach skierowanych w „lewo" mają w sobie coś „awanturniczego”, a ich dynamika i przyspieszenie wzrastają ${ }^{49}$.

Przeciwnie jest w przypadku odwrotnego kierunku.

Ruch w „prawo”, ku skrępowaniu, jest ruchem w kierunku domu [podkreślenie w oryginale - P.Sz.]. Jest on związany z pewnym znużeniem i jego celem jest spoczynek. Im bliżej „prawej” strony, tym bardziej jest on powolny i niemrawy - napięcia form zmierzających ku stronie „prawej” maleją, a możliwości ruchu stają się coraz bardziej ograniczone ${ }^{50}$.

Do tych dwóch podstawowych kierunków ruchu artysta dodaje wznoszenie się i opadanie. Jako skojarzenia dotyczące "góry” i „dołu” wskazuje niebo i ziemię. Odnosząc te kierunki działania do sytuacji teatralnych, z łatwością zauważamy analogie. Aktorzy na scenie zwykle przemieszczają

\footnotetext{
47 Ibidem, s. 130.

48 Ibidem, s. 134.

49 Ibidem, s. 135.

50 Ibidem.
} 
się w prawo lub w lewo i te kierunki ruchu mają związek z treścią przedstawienia. Czasami tylko, w szczególnych sytuacjach, uwzględniany jest ruch w górę lub w dół.

Kandinsky uświadamiał sobie interdyscyplinarny charakter opisywanych prawidłowości kinetycznych, ale teatru jako szczególnie istotnego punktu odniesienia nie wskazywał. Sugerował raczej sens ogólnoludzki, pisząc, że „literacki” posmak

ujawnia głębokie powinowactwa istniejące pomiędzy rozmaitymi dziedzinami sztuki, co z kolei pozwala przeczuwać głęboko leżące wspólne korzenie wszelkiej twórczości, a w końcu wszelkiej duchowej ludzkiej działalności ${ }^{51}$.

Narzucającym się wnioskiem z tych rozważań jest uznanie, że analizując „głębokie powinowactwa istniejące pomiędzy rozmaitymi dziedzinami sztuki", brać należy pod uwagę nie tylko wielokrotnie opisywane odniesienie do muzyki, lecz również istotną z punktu widzenia performatyki relację do teatru.

„Aktorami” w obrazach W. Kandinsky’ego były przez większą część jego twórczości zarówno kształty nieprzedstawiające, jak i odtworzone postacie ludzkie i przedmioty. W jaki sposób artysta opisuje ich wybór w toku komponowania obrazu?

Weźmy kompozycję romboidalną - pisze - utworzoną na przykład przez jakąś grupę postaci. Przyglądamy się jej z uwagą i stawiamy sobie pytanie: czy naprawdę figury ludzkie są w niej niezbędne, czy też można je zastąpić przez widoki innych przedmiotów, bez szkody dla wewnętrznego [podkreślenie w oryginale - P.Sz.] podstawowego tonu całej kompozycji? Jeżeli tak, to mamy do czynienia z wypadkiem, w którym wyraz przedmiotu nie tylko nie wspomaga działania formy abstrakcyjnej, lecz wręcz jej przeszkadza: obojętny wyraz formy przedmiotowej osłabia działanie formy abstrakcyjnej. Jest tak rzeczywiście nie tylko ze względów logicznych, ale i artystycznych. Powinno się zatem w tym wypadku znaleźć przedmiot bardziej pasujący do wewnętrznego tonu abstrakcyjnej formy (na zasadzie harmonii lub kontrastu) albo cała forma powinna być czysto abstrakcyjna ${ }^{52}$.

Powyższy cytat jeszcze raz wyraźnie wskazuje, że na etapie komponowania obrazu artysta stosował również zasadę empatii. Przedmiotem wczucia był zarówno cały tworzony układ elementów, jak i poszczególne wprowadzane do niego składniki. O wyborze ich decydowała nie wartość czysto wzrokowa, „dekoracyjna”, lecz przypisywany im wyraz emocjonalny. Podsumowując powyższe rozważania, W. Kandinsky pisał:

51 Ibidem, s. 134.

52 W. Kandyński, O duchowości..., s. 71-72. 
Każdy przedmiot (niezależnie od tego, czy został stworzony bezpośrednio przez „naturę” czy ręką ludzką) jest bytem obdarzonym własnym życiem i wypływającym stąd nieuniknionym działaniem. Skutki tego są rejestrowane przez „podświadomość” (gdzie pozostają aktywne i twórcze) ${ }^{53}$.

W cytacie tym kierunek oddziaływania elementu plastycznego został ujęty w taki sposób, że jako czynnik aktywny wskazane zostały składniki dane w percepcji wzrokowej. To dostrzeżenie ich „życia” wywoływać ma emocje. Przedstawiciele estetyki empatii wielokrotnie jednak podkreślali, że podczas aktu wczucia dochodzi do utożsamienia tego, co pochodzi od przedmiotu, z tym, co wnosi podmiot, tak dalece, iż to, co przenieśliśmy na przedmiot, uważamy za uzyskane od niego.

Na zakończenie odnieśmy zagadnienia podejmowane tu na podstawie tekstów W. Kandinsky'ego do jego obrazów. Historycy sztuki rozważając przejście artysty od malarstwa przedstawiającego do abstrakcji, chętnie zestawiają dwie prace z 1912 r. Sceneria pierwszego obrazu, zatytułowanego Dama w Moskwie, zaaranżowana została elementami przedstawiającymi perspektywę ulicy, dorożkę i posłańca. Na pierwszym planie pokazana została tytułowa dama stojąca obok okrągłego stolika. Oprócz tego wprowadzone zostały składniki nieprzedstawiające: czarna plama z dodanym czerwonym elementem, (przypominająca nieco tors ludzki i głowę) oraz czerwono-różowy okrągły kształt znajdujący się po lewej stronie kobiety. Najbardziej dynamicznym składnikiem kompozycji jest czarna plama, która zdaje się poruszać ukośnie w górę, przesłaniając słońce. Obraz przypomina realistyczną scenografię do jakiejś sztuki teatralnej z bohaterką przedstawienia umieszczoną na pierwszym planie. Akcję dramatu można odczytywać jako agresję czarnej plamy. Ulrike Becks-Malorny, zakładając, że kobieta na pierwszym planie jest główną postacią, pisze: „Pędzi ku niej czarna plama, która zaczyna już przesłaniać samo słońce" ${ }^{54}$. Wskazuje też na możliwość symbolicznego odczytania tej sytuacji w nawiązaniu do teozofii, jako wdzierania się „mroków materializmu” w sferę komunikacji między „wieczną światłością" i poszukującym oświecenia stworzeniem ${ }^{55}$. Podobna treść została podjęta przez W. Kandinsky'ego w pochodzącym z tego samego roku obrazie Czarna plama I. Nastąpiła w nim jednak zmiana „scenografii” i części „bohaterów”. Nie ma już konstrukcji perspektywicznej. Sugestie relacji przestrzennych między elementami plastycznymi wprowadzane

53 Ibidem, s. 72.

54 U. Becks-Malorny, Wassily Kandinsky. 1866-1944. Droga ku abstrakcji, tłum. C. Jenne, Warszawa 1999, s. 102.

55 Interpretację teozoficzną tych obrazów przedstawia Sixten Ringbom w książce The Sounding Cosmos. A Study in the Spiritualism of Kandinsky and the Genesis of Abstract Painting, Åbo 1970, s. 100-103. 
są za pomocą właściwości kolorów. W obrazie można doszukać się podobieństwa miedzy niektórymi układami plam barwnych, a kopułami cerkwi powozem z trójką koni oraz łodzią z dwiema płynącymi nią osobami. Głównym „bohaterem” staje się czarna plama o nieco zmienionym kształcie.

Plama na obrazie olejnym - pisze U. Becks-Malorny - jest czarnym, nerkowatym kształtem, który z centrum przesunął się nieco w prawo. Czarno-niebieski łuk na lewo od niej i kolista forma ponad nią, przypominająca słońce, wyznaczają ukośny kierunek ruchu, utrzymujący kompozycję wespół z czarnymi elementami graficznymi w pełnej napięcia równowadze $\mathrm{e}^{56}$.

Ogólna zwartość treściowa obrazu jest więc podobna, jednak „spektakl” zainscenizowany został inaczej, przy mniejszym wykorzystaniu elementów przedstawiających. Na czarnej plamie występuje poza tym rozchodzący się promieniście układ białych smug farby, który w pismach teozofów interpretowany był jako „eksplozywny gniew”57. Swoisty spektakl, jakim zgodnie z założeniami W. Kandinsky'ego są jego obrazy, rozgrywa się tu pomiędzy elementami abstrakcyjnymi. Zachowuje jednak ruch i życie.

Artysta zdawał sobie sprawę z konsekwencji swych koncepcji dla teatru, choć w przeciwieństwie do odniesień muzycznych nie akcentował ich w swych głównych rozprawach na temat sztuk plastycznych. Świadczą o tym teksty Über Bühnenkomposition i Der gelbe Klang opublikowane w 1912 r. w almanachu Der Blaue Reiter, które w znacznym stopniu nawiązywały do jego koncepcji malarskich. Pierwszy zawierał gwałtowny atak na teatr XIX-wieczny i demaskował utopijność wagnerowskiego Gesamtkunstwerk. Przedstawiał też koncepcję „kompozycji scenicznej” opartą na wewnętrznej jedności elementów muzycznych, malarskich, ruchu itp. Elementem łączącym była omówiona tu zasada wewnętrznego brzmienia, ujawniająca się przez „dźwięk muzyczny i jego wyraz ruchowy”, „dźwiękowość psychofizyczną i jej wyraz ruchowy przejawiający się poprzez istoty i przedmioty” oraz „dźwięk chromatyczny i jego wyraz ruchowy”58. Drugi tekst, zatytułowany Der gelbe Klang, był scenariuszem tego typu przedstawienia. Oparte było ono, jak pisze Denis Bablet,

na wierze w zasadniczą tożsamość sztuk, w zgodność, która umożliwia ich wzajemne przenikanie. Jest zatem „kompozycją” w podwójnym rozumieniu

56 U. Becks-Malorny, op. cit., s. 102.

57 Por. G. Sztabiński, Mistyczny wymiar malarstwa. Teozofia w twórczości Wassily Kandinsky'ego i Pieta Mondriana, w druku.

${ }^{58}$ Cyt. za: D. Bablet, Rewolucje sceniczne XX wieku, tłum. Z Strzelecki, K. Mazur, Warszawa 1980, s. 32. 
słowa, artystyczną i chemiczną: „Zawiera trzy elementy, które jako środki zewnętrzne służą znaczeniu wewnętrznemu"59.

Elementy te wymieniłam wyżej. Zachodzić miały między nimi związki „chemicznych" reakcji opartych na zastosowaniu elementów plastycznych przedstawiających i nieprzedstawiających, dźwięku i ruchu. Swoistość tej koncepcji polegała jednak na tym, ze kolor i światło nie ilustrowały tu muzyki, podobnie jak muzyka ich nie objaśniała. Każdy ze środków, jak pisze D. Bablet, stanowił składnik polifonicznej całości dzieła ${ }^{60}$.

Kandinsky nie zrealizował Der gelbe Klang w formie scenicznej. Bablet rozpatruje jego koncepcję jako zapowiedź teatru abstrakcyjnego. Teatr taki zmieniał charakter przedstawienia, ale z istotą sytuacji teatralnej nie zrywał. Czy w podobny sposób należy potraktować przedstawioną tu koncepcję malarską W. Kandinsky'ego? Artysta, o czym pisałam na początku tego tekstu, wyrażał pragnienie wyjścia poza obraz ku „życiu”. Biorąc pod uwagę tok jego rozważań i ewolucję twórczości, można powiedzieć, że wyszedł poza tradycję malarską, ale poszukując odmian ruchów właściwych dla elementów plastycznych zatrzymał się na teatrze. Być może powodem tego było jego przekonanie, że nawet rozbijając w swej twórczości „niby-szybę”, artysta nie wkracza w surową rzeczywistość. Jego działalność przestałaby wtedy być sztuką. Może on tylko dążyć do znalezienia takiej formy, która rzeczywistości pozaartystycznej będzie bliższa. Teatr uwzględniający żywe osoby, ruch i dźwięk wydawał się W. Kandinsky'emu taką dziedziną sztuki.

\section{BIBLIOGRAFIA}

Alberti L.B., O malarstwie, tłum. L. Winniczuk, Wrocław 1963.

Bablet D., Rewolucje sceniczne XX wieku, tłum. Z Strzelecki, K. Mazur, Warszawa 1980.

Balme Ch., Wprowadzenie do nauki o teatrze, tłum. W. Dudzik, M. Leyko, Warszawa 2002.

Becks-Malorny U., Wassily Kandinsky. 1866-1944. Droga ku abstrakcji, tłum. C. Jenne, Warszawa 1999.

Goldberg R., Performance. Live Art Since 1960, London-New York 1998.

Happenings and Fluxus, red. H. Sohm, Köln 1970.

Jappe E., Performance - Ritual - Prozeß: Handbuch der Aktionskunst in Europa, München -New York 1993.

Kandyński W., Punkt i linia a płaszczyzna. Przyczynek do analizy elementów malarskich, tłum. S. Fijałkowski, Warszawa 1986.

${ }^{59}$ Ibidem.

${ }^{60}$ Ibidem. 
Kandyński W., O duchowości w sztuce, tłum. S. Fijałkowski, Łódź 1996.

Kirby M., Happenings, New York 1965.

Komza M., Żywe obrazy. Między scena, obrazem i książką, Wrocław 1995.

Osborne H., Aesthetics and Art Theory: An Historical Introduction, London 1968.

Pawłowski T., Happening, Warszawa 1982.

Performance. Wybór tekstów, red. G. Dziamski, H. Gajewski, J.S. Wojciechowski, Warszawa 1984.

Poprzęcka M., Akademizm, Warszawa 1977.

Ringbom S., The Sounding Cosmos. A Study in the Spiritualism of Kandinsky and the Genesis of Abstract Painting, Åbo 1970.

Rzepińska M., Wstęp, [w:] L.B. Alberti, O malarstwie, tłum. L. Winniczuk, Wrocław 1963.

Sztabiński G., Mistyczny wymiar malarstwa. Teozofia w twórczości Wassily Kandinsky'ego i Pieta Mondriana [w druku].

\section{SUMMARY}

\section{Life in the Image. On Wassily Kandinsky's Approach to Painting}

The starting point for the analyses presented in the article is Wassily Kandinsky's book Point and Line to Plane, considered as the basis for interpreting his oeuvre. In his introduction to the book, the artist made the distinction between two aspects of experiencing every phenomenon - external and internal. Kandinsky's intention was to aim towards "life", although not through a faithful reproduction of its external manifestations. The artist wanted to discover "life" in the image by going beyond the traditional, mimetic understanding of painting.

In her article, the author, on the one hand, examines Kandinsky's aspirations to bring art closer to life by accentuating the direct influence of artistic elements, whose "inner sound" would give the impression of communing with living entities. On the other hand, she analyses the artist's theoretical concepts and painterly output in relation to theatre and performance art, that is disciplines that involve the activity of living people surrounded by real objects. 